
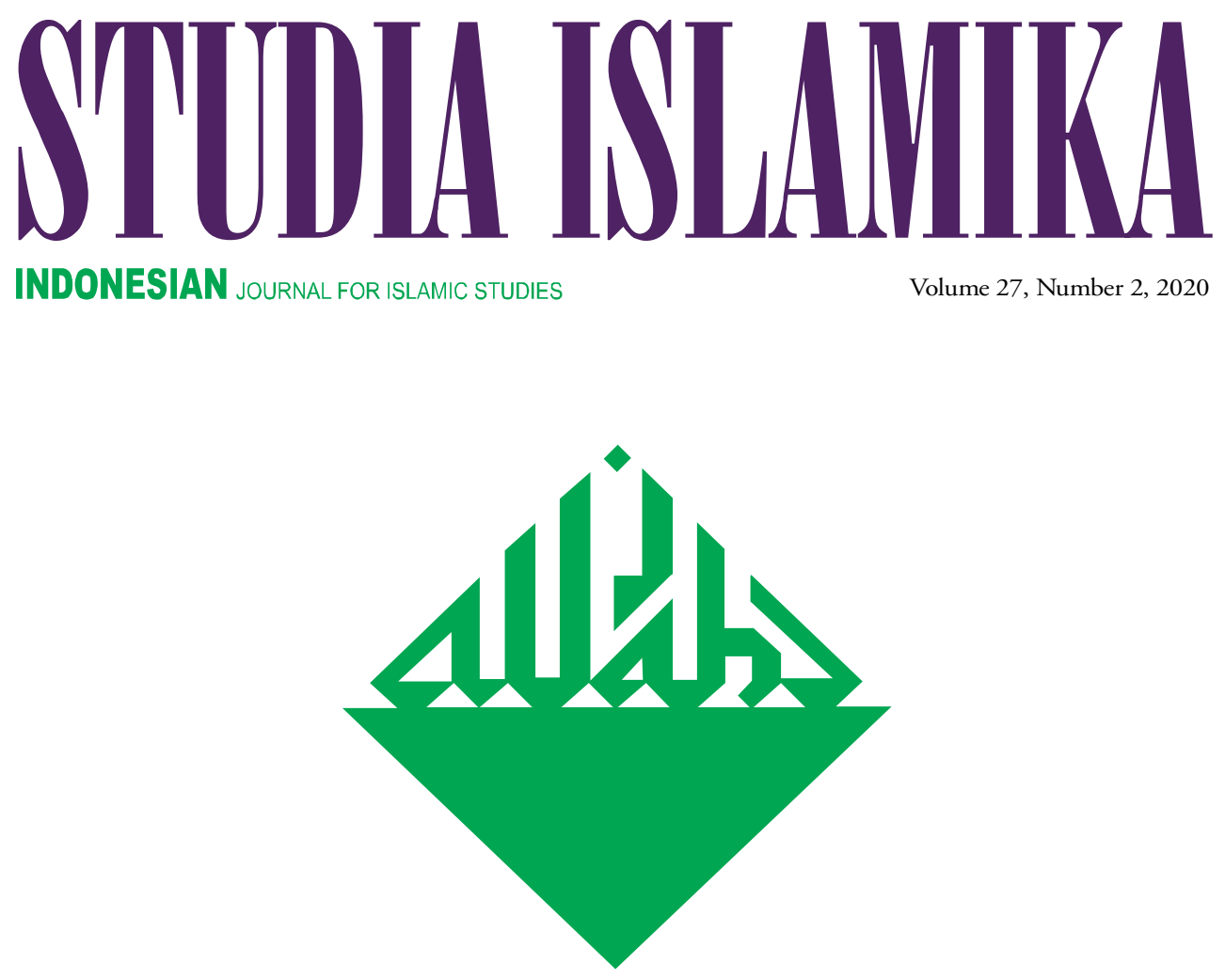

IMAGES OF MAKKAH

and the Haju in South Thailand:

An Ethnographic and Theological Exploration

Christopher Mark Joll \& Srawut Aree

Revitalizing Hadhrami Authority:

New Networks, Figures and Institutions

AMONG HABÄIB IN INDONESIA

Syamsul Rijal

Protecting Women from Domestic Violence:

Islam, Family LaW, and the State in Indonesia

Alfitri 
STIUDLA ISLAMIIIKA 



\section{STIDIIA ISLAVIIIKA}

Indonesian Journal for Islamic Studies

Vol. 27, no. 2, 2020

EDITOR-IN-CHIEF

Azyumardi Azra

MANAGING EDITOR

Oman Fathurahman

EDITORS

Saiful Mujani

Jambari

Didin Syafruddin

Jajat Burhanudin

Fuad Jabali

Ali Munhanif

Saiful Umam

Dadi Darmadi

Jajang Jahroni

Din Wahid

Euis Nurlaelawati

INTERNATIONAL EDITORIAL BOARD

M. Quraish Shihab (Syarif Hidayatullah State Islamic University of Jakarta, INDONESIA)

Martin van Bruinessen (Utrecht University, NETHERLANDS)

John R. Bowen (Washington University, USA)

M. Kamal Hasan (International Islamic University, MALAYSIA)

Virginia M. Hooker (Australian National University, AUSTRALIA)

Edwin P. Wieringa (Universität zu Köln, GERMANY)

Robert W. Hefner (Boston University, USA)

Rémy Madinier (Centre national de la recherche scientifique (CNRS), FRANCE)

R. Michael Feener (National University of Singapore, SINGAPORE)

Michael F. Laffan (Princeton University, USA)

Minako Sakai (The University of New South Wales, AUSTRALIA)

Annabel Teh Gallop (The British Library, UK)

Syafaatun Almirzanah (Sunan Kalijaga State Islamic University of Yogyakarta, INDONESIA)

ASSISTANT TO THE EDITORS

Testriono

Muhammad Nida' Fadlan

Rangga Eka Saputra

Abdullah Maulani

ENGLISH LANGUAGE ADVISOR

Benjamin J. Freeman

Daniel Peterson

Batool Moussa

ARABIC LANGUAGE ADVISOR

Tb. Ade Asnawi

Ahmadi Usman

\section{COVER DESIGNER}

S. Prinka 
STUDIA ISLAMIKA (ISSN 0215-0492; E-ISSN: 2355-6145) is an international journal published by the Center for the Study of Islam and Society (PPIM) Syarif Hidayatullah State Islamic University of Jakarta, INDONESIA. It specializes in Indonesian Islamic studies in particular, and Southeast Asian Islamic studies in general, and is intended to communicate original researches and current issues on the subject. This journal warmly welcomes contributions from scholars of related disciplines. All submitted papers are subject to double-blind review process.

STUDIA ISLAMIKA has been accredited by The Ministry of Research, Technology, and Higher Education, Republic of Indonesia as an academic journal (Decree No. 32a/E/KPT/2017).

STUDIA ISLAMIKA has become a CrossRef Member since year 2014. Therefore, all articles published by STUDIA ISLAMIKA will have unique Digital Object Identifier (DOI) number.

STUDIA ISLAMIKA is indexed in Scopus since 30 May 2015.

Editorial Office:

STUDIA ISLAMIKA, Gedung Pusat Pengkajian

Islam dan Masyarakat (PPIM) UIN Jakarta,

Jl. Kertamukti No. 5, Pisangan Barat, Cirendeu,

Ciputat 15419, Jakarta, Indonesia.

Phone: (62-21) 7423543, 7499272, Fax: (62-21) 7408633;

E-mail: studia.islamika@uinjkt.ac.id

Website: http://journal.uinjkt.ac.id/index.php/studia-islamika

Annual subscription rates from outside Indonesia, institution: US\$ 75,00 and the cost of a single copy is US\$ 25,00; individual: US\$ 50,00 and the cost of a single copy is US\$ 20,00 . Rates do not include international postage and handling.

Please make all payment through bank transfer to: PPIM, Bank Mandiri KCP Tangerang Graha Karnos, Indonesia, account No. 101-00-0514550-1 (USD),

Swift Code: bmriidja

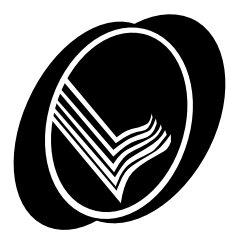

Harga berlangganan di Indonesia untuk satu tahun, lembaga: Rp. 150.000,-, harga satu edisi Rp. 50.000,-; individu: Rp. 100.000,-, harga satu edisi Rp. 40.000,-. Harga belum termasuk ongkos kirim.

Pembayaran melalui PPIM, Bank Mandiri KCP Tangerang Graha Karnos, No. Rek: 128-00-0105080-3 


\section{Table of Contents}

\section{Articles}

205 Christopher Mark Joll \& Srawut Aree

Images of Makkah

and the Hajj in South Thailand:

An Ethnographic and Theological Exploration

239 Syamsul Rijal

Revitalizing Hadhrami Authority:

New Networks, Figures and Institutions

among Habäib in Indonesia

273 Alfitri

Protecting Women from Domestic Violence:

Islam, Family Law, and the State in Indonesia

309 Muhammad Irfan Helmy \& Ahmad Ali Nurdin Al-Kifāḥ min ajli dawlah Islāmīyah 'abra al-masār al-dīmuqrātī:

Tajribat al-Ḥizb al-Islāmī al-Mālizī (PAS)

343 Abdul Wabid Hasyim

Al-Ṭarīqah al-Naqshabandīyah al-Khālidīyah fì Cianjur, Jawa al-Gharbìyah:

Ta'ālimuhā wa tuqūsuhā wa taṭawwurātuhā 


\section{Book Review}

385 Wahyudi Akmaliah

Mengartikulasikan Suara Alternatif

Muslim Asia Tenggara

\section{Document}

397 Irfan Abubakar \& Idris Hemay

Pesantren Resilience:

The Path to Prevent Radicalism

and Violent Extremism 


\section{Document}

\section{Pesantren Resilience: The Path to Prevent Radicalism and Violent Extremism}

\section{Irfan Abubakar \& Idris Hemay}

The phenomena of radicalism and violent extremism in Indonesia, in some cases, cannot be separated from pesantren

(Islamic boarding schools); some jihadis (read: terrorists) are pesantren graduates. However, as an educational institution that has rooted in the Indonesia Muslim communities, the majority of pesantren carry the spirit of religious moderation. They have even produced many alumni promoting peaceful, tolerant, and democratic views of Islam. Some pundits have confirmed the moderate character of pesantren. Azyumardi Azra, in his review on the results of the study of the Center for the Study of Religion and Culture (CSRC) and the Center for the Study of Islam and Society (PPIM, Pusat Pengkajian Islam dan Masyarakat) UIN Jakarta (The Jakarta Post, 22 December 2019), underlines that pesantren has contributed to fostering the understanding of moderate Islam (wasatizyah). Pesantren is different from Islamic educational institutions in other Muslim countries, such as Pakistan, Yemen, Afghanistan, etc. In those countries, many madrasahs (Islamic schools) become a place of a breeding ground for a radical 
understanding of Islam. The CSRC and PPIM UIN Jakarta's study (2019) shows that pesantren has "social resilience" which can hinder them from the influence of radical ideology, although they still have some vulnerabilities. Pesantren resilience is resulted by their capacity in empowering their social capitals that have been existed in three social connectivity: social bonding, social bridging, and social linking.

\section{Social Bonding and Pesantren Identity}

Pesantren resilience is formed first by the existence of social cohesion by which pesantren have built their social identity. By such identity, pesantren can fortify their community from new identities propagated by radical actors. Traditional pesantren, which most of them affiliate with Nahdhatul Ulama (NU), for example, rely on social cohesion to the figures of charismatic kiai and the learning traditions of classical Islamic textbooks (it is usually called kitab kuning or the yellow book). The social capital of the kiai and kitab kuning are interrelated because the existence of the kiai is determined by their ability to master kitab kuning. Thus, the capability of the kiai in interpreting the classical texts determines the continuity of the kitab kuning book tradition.

Unlike the traditional pesantren, Gontor and its affiliates, known as modern pesantren, rely on their "social bonding" on a set of spiritual values known as the "Panca Jiwa" (Five Spiritual Values), namely: sincerity, modesty, Islamic brotherhood (ukhiuwah islämīyah), independence, and freedom. The Panca Jiwa becomes a philosophical parameter to filter out new ideologies coming from outside, including radical and extremist ideologies. The value of freedom, for example, is a kind of philosophical reference in addressing sectarianism in Islam. Their motto "Gontor Standing on Top and for All Groups" implies respect for non-sectarian attitude. In practice, the leaders of Pesantren Gontor recognize that there is a deviation from the Panca Jiwa in which several Gontor alumni involved in the radical movements -in this case, represented by Abubakar Ba'asyir, a role model of jihadists in Indonesia. The following expression reflects this deviation: "Ba'asyir is indeed a Gontor's graduate, but Gontor is not Ba'asyir."

Then, modernist pesantren, which usually affiliate with modernist Islamic organizations such as Muhammadiyah and Persis, build their identities based on their organization's identities. The more obedient pesantren to the referral value of their organizations is, the stronger their 
social cohesiveness is. Perhaps because Muhammadiyah pesantren have long been established, such as Darul Arqam Garut, they are relatively able to represent the values of Muhammadiyah in their educational policies. Regarding their affection to the nation, the Muhammadiyah pesantren generally show a certain appreciation for the "Results of Muhammadiyah Congress 2015" in Makassar, which supported the Republic of Indonesia as "Dār al-'ahdi wa al-shahädah" (the state based on national consensus and binding recognition).

Among the typologies of pesantren, the Salafi pesantren are relatively new in Indonesia Muslim communities. They are characterized by loyalty to the doctrine of Salafism widely inspired and practiced in Saudi Arabia. To face radical and extremist ideologies, the Salafi pesantren generally refer to the bughät doctrine, that Muslims are forbidden to rebel against a legitimate ruler. However, acceptance of this doctrine among Salafists themselves is diverse. Some Salafi schools accept the doctrine of bughät dogmatically, others accept it with certain limitations. Some Salafi Purist pesantren (such as Abu Hurairoh, Mataram, and al-Furqan al-Islamy, Gresik) reject radicalism because it is considered contrary to the bughät doctrine; they also reject any political activism that could potentially risk bughät, including demonstrations against government policies. Meanwhile, Salafi Haraki and Salafi Tanzimi (latter a part of Purist) which are politically oriented, at different levels, accept the bughät doctrines loosely. Salafi Tanzimi pesantren (such as Wahdah Islamiyah/WI Pesantren) and Salafi Haraki pesantren (such as Pesantren al-Salam, Bima) although both reject terrorist ISIS (Islamic State in Iraq and Syria), they tend to be more critical to the government and agree to the establishment of the Islamic caliphate.

However, in the context of support for democracy, Salafi pesantren are generally ambivalent. The Salafi Tanzimi and Haraki pesantren, although they support the establishment of the caliphate, accept democracy -to some degree. While the Salafi Purist pesantren, although they reject ISIS and reject the establishment of the caliphate, they do not support democracy.

\section{National Orientation of Pesantren}

Another characteristic of pesantren resilience is the ability to balance between preserving their identities and building social connections with different groups ideologically. As a result, pesantren from all typologies 
accept relationships with non-Muslim groups, but with certain restrictions: the relationships do not fuse the faith ('aqidab), do not interfere with each other, and do not compromise the ethics of food and clothing. Encounters with non-Muslims are not prohibited, but it is not encouraged. Also, the programs held to encounter with nonMuslims are very limited. Among those few, the Muhammadiyah's pesantren, Darul Arqam Garut, West Java, allows their students to visit the churches as part of a field study in Sociology, and traditional pesantren in Pandegelang, An-Nizhomiyyah Pandeglang, Banten, works with the community of Catholic church.

The ability of pesantren to embrace diversity is varied and limited within the framework of their theological preference and culture. Pesantren Gontor, for example, although they do not encourage the experience of physical encounters to non-Muslims, they introduce the diversity of religions to senior students through the teaching of Kitāb al-Adyān (The Religions) written by Mahmud Yunus, an Indonesian education expert. Salafi pesantren generally do not encourage the strengthening of nationalism and tolerance. There is a tendency to reject the democratic system among the Salafi Purist Pesantren; this can potentially erode the national identity. Even though they prohibit bughāt (rebellion or disobedience to the legitimate ruler), there is no guarantee that their students will commit to the doctrine of bughät whenever there are an opportunity and movement to replace the democratic system to the Islamic-based political system. Hence, amidst those limits of national commitments, many figures recommend the strengthening of national values in pesantren. Fadly Azhar, a representative from the Directorate of Diniyah Education and Pesantren of the Ministry of Religious Affairs (MORA), in a review of this study (December 2019), considers that the Ministry should facilitate training on strengthening national outlook (wawasan kebangsaan) and equality in Pesantren. Fadly Azhar also said that radicalism and extremism are not merely religious issues, but partly related to the problem of social-economic injustice and inequality.

Therefore, while the attitudes of pesantren which are relatively tolerant towards non-Muslims, they generally have a negative attitude towards Shi'ites and Ahmadis. No pesantren have initiated a dialogue about Shi'ites and Ahmadis. Generally, they tend to depart from negative prejudice for those Muslim minority groups in Indonesia. Even the Pesantren Gontor, which has ukhüwah islämīyah (Islamic 
brotherhood) values and religious freedom, does not show a positive attitude towards Shi'ites and Ahmadis. Furthermore, pesantren having agenda to purify Islamic teachings such as the Salafi pesantren will naturally be more negative attitudes towards Muslim minority groups considered heretical.

\section{Relationship with the State}

The integration of pesantren into the national education system is the crucial factor that distinguishes pesantren from Islamic educational institutions in other Muslim countries whom they tend to be more vulnerable to radical understanding (Azra et.al., 2006). This study confirms Azra's observations and founds that pesantren resilience is also determined by the constructive relationships between pesantren and the state. Their harmonized relationships with the state create a protective factor, even though their ability for "social bridging" is frail. The "social link" with the government is manifested in the form of integration of pesantren into the national education system; it can strengthen the protective factors existed in pesantren. For example, Pondok Modern Tazakka, Batang, Central Java, get mu'ädalah (certification) from the MORA in 2016; then the government asked them to develop modules for conflict resolution training to Afghanistan's Islamic preachers who had a comparative study in Indonesia.

One significant implication of "social linking" is the implementation of the government curriculum in pesantren. The majority of pesantren teach their students the subject of Civic Education (PKN, Pendidikan Kewarganegaraan). Some modernist pesantren offer sociology and Islamic Education (PAI, Pendidikan Agama Islam) subjects. Some pesantren are wittingly made $\mathrm{PKN}$ as a lesson to counter radical narratives. However, in some other pesantren, PKN is seen as merely a formal requirement to obtain recognition from the government. In latter pesantren, they do not provide a certified teacher to teach PKN, but they just provide modules or textbooks to be read by students. Azyumardi Azra worries that the pesantren's relationship with the government is merely a formality. Therefore, Azra, as quoted by The Jakarta Post, 22 December 2019, also emphasizes that the government should monitor the "hidden curriculum" in pesantren, an informal curriculum carried out by certain religious orientations driven by pesantren leaders; it is not available in the official curriculum. Ahmad 
Zayadi, a former Director of Diniyah and Pesantren, acknowledges that the MORA had tried to monitor the pesantren's curriculum. However, this task could not only be borne by this Ministry, but it must entangle other government institutions, particularly BNPT (National Counterterrorism Agency) (The Jakarta Post, December 22, 2019).

\section{The Establishment of Pesantren Resilience}

The establishment of resilience in pesantren aims to strengthen the pesantren by eliminating vulnerable risk factors usually originated from four factors: connections with radical actors or networks; the exposure to access radical information through the internet; indoctrinated pedagogy in teaching religion; and the acceptance of radical groups' propaganda that Muslim is being victimized.

Facing the above risk factors, pesantren generally carry out "resilience-building" which still refers to the existed social capital. They prevent their members from contacting radical movements and ideas, at the same time trying to delegitimize radical ideologies.

The kiai, in traditional pesantren (including Dayah in Aceh), always warn their students to stay away from radical organizations and movements; HTI (Hizbut Tahrir Indonesia) is on the list of warned organization. Also, kiai play a role in contextualizing the interpretations of the kitab kuning, where they dig up verses of the kitab kuning that can be used to delegitimize radical interpretations on the Quran and the Hadith. In Pesantren Gontor which has been established around for almost a century, there is a tendency that they keep staying with their social capital and do not consider urgent to carry out new initiatives for "resilience-building" in their pesantren. The managements of Pesantren Gontor seem to believe that "resilience-building" is inherent in their efforts to maintain the quality of their education program namely Kulliyatul Mu'allimin al-Islamiyyah (KMI), a level of education that is formally equivalent to senior high school. There is also an attempt to screen the sources of students' reading materials; sources of readings that contradict the doctrine of Ahlussunnah wal Jamaa'ah are forbidden. However, survey data shows that respondents from the Pesantren Gontor and its affiliates still quite agree with the obligation for Muslims to establish the Islamic caliphate (37\%).

The Muhammadiyah and Persis's pesantren also do not perform transformative programs, but they support the government in socializing 
counter-radicalism or strengthening of national outlook. However, the finding also shows that there are still a lot of respondents from modernist pesantren who sympathize with the establishment of Islamic caliphate; respectively, Muhammadiyah's pesantren (41\%), and Persis's pesantren $(54 \%)$.

Some Salafi Purist pesantren do not conduct any resilience programs in countering radicalism, except they only maximize the bughät doctrine to delegitimize radical ideology. This doctrine is considered influential in counteracting the propaganda of the caliphate where there is a strong tendency among the Salafi Purist pesantren to reject the idea of the caliphate (77\%). Some others, like Wahdah Islamiyah's pesantren, adopt programs offered by the government. However, they are still ambivalent regarding national commitments.

Although some pesantren monitor over reading materials and digital media accessed by their students, yet the programs conducted intentionally to reduce prejudice and hatred for other groups with different identities are very limited. The pesantren pedagogy generally does not emphasize the importance of critical thinking in evaluating information, especially related to religion. In many pesantren, especially Salafi pesantren, memorization (hafalan or tahfiz) is the main priority in learning processes. Pesantren resilience for the long term will be mainly determined by the development of critical thinking traditions of students, still without diminishing the identity of pesantren. Amidst hoaxes and expressions of hatred flooding in digital communication, the students given critical thinking teaching are expected to be able to distinguish factual information and provocative rhetoric.

\section{Closing Remarks}

Pesantren, from various typologies, have empowered their social capital to bear up from the influence of radical ideology. The stronger of pesantren builds their social identity, the stronger their resistance from the push and pull factors of radicalization is.

However, such socio-religious identities alone are not enough for pesantren to build up their resilience; they need to balance and adapt their identity with national identity within the framework of ethnic, cultural, and religious diversity. The more pesantren experience in dialogue and finding a coexistence between Islam and national identities is, the higher the resilience to radicalism and violent extremism is. 
To a certain degree, some pesantren with adequate resilience, such as pesantren affiliated with NU, have instead blurred the dividing line between both identities; they have placed the values of love the nation ( $h u b$ al-watān) as an important component of the pesantren identity.

Efforts to harmonize the micro identity of pesantran and macro national identity have not been possible without involving the state's institutions in developing an integrated national education system. Pesantren has been considered as one of the pivotal factors in such national educational integration, and the active involvement of pesantren in the processes of developing the national education system has increasingly strengthened their resilience in dealing with radicalism and violent extremism. This study has tried to analyze the factors of pesantren resilience to radicalism and violent extremism. Policymakers are expected to understand the framework of social relations (social bonding, social bridging, and social linking) as determining factors in pesantren resilience. Therefore, efforts conducted by the government to increase the national commitment of pesantren, for example, need to be based on understanding and sensitivity to each typology of pesantren and how they build relationships with different social groups and with the government.

Irfan Abubakar, Center for the Study of Religion and Culture (CSRC) Syarif Hidayatullah State Islamic University (UIN) of Jakarta, Indonesia. Email irfan.abubakar@uinjkt.ac.id.

Idris Hemay, Center for the Study of Religion and Culture (CSRC) Syarif Hidayatullah State Islamic University (UIN) of Jakarta, Indonesia. Email: idris.hemay@uinjkt.ac.id. 


\section{Guidelines}

\section{Submission of Articles}

tudia Islamika, published three times a year since 1994, is a bilingual (English and Arabic), peer-reviewed journal, and specializes in Indonesian Islamic studies in particular and Southeast Asian Islamic studies in general. The aim is to provide readers with a better understanding of Indonesia and Southeast Asia's Muslim history and present developments through the publication of articles, research reports, and book reviews.

The journal invites scholars and experts working in all disciplines in the humanities and social sciences pertaining to Islam or Muslim societies. Articles should be original, research-based, unpublished and not under review for possible publication in other journals. All submitted papers are subject to review of the editors, editorial board, and blind reviewers. Submissions that violate our guidelines on formatting or length will be rejected without review.

Articles should be written in American English between approximately 10.000-15.000 words including text, all tables and figures, notes, references, and appendices intended for publication. All submission must include 150 words abstract and 5 keywords. Quotations, passages, and words in local or foreign languages should 
be translated into English. Studia Islamika accepts only electronic submissions. All manuscripts should be sent in Ms. Word to: http:// journal.uinjkt.ac.id/index.php/studia-islamika.

All notes must appear in the text as citations. A citation usually requires only the last name of the author(s), year of publication, and (sometimes) page numbers. For example: (Hefner 2009a, 45; Geertz 1966, 114). Explanatory footnotes may be included but should not be used for simple citations. All works cited must appear in the reference list at the end of the article. In matter of bibliographical style, Studia Islamika follows the American Political Science Association (APSA) manual style, such as below:

1. Hefner, Robert. 2009a. "Introduction: The Political Cultures of Islamic Education in Southeast Asia," in Making Modern Muslims: The Politics of Islamic Education in Southeast Asia, ed. Robert Hefner, Honolulu: University of Hawai'i Press.

2. Booth, Anne. 1988. "Living Standards and the Distribution of Income in Colonial Indonesia: A Review of the Evidence." Journal of Southeast Asian Studies 19(2): 310-34.

3. Feener, Michael R., and Mark E. Cammack, eds. 2007. Islamic Law in Contemporary Indonesia: Ideas and Institutions. Cambridge: Islamic Legal Studies Program.

4. Wahid, Din. 2014. Nurturing Salafi Manhaj: A Study of Salafi Pesantrens in Contemporary Indonesia. PhD dissertation. Utrecht University.

5. Utriza, Ayang. 2008. "Mencari Model Kerukunan Antaragama." Kompas. March 19: 59.

6. Ms. Undhang-Undhang Banten, L.Or.5598, Leiden University.

7. Interview with K.H. Sahal Mahfudz, Kajen, Pati, June $11^{\text {th }}$, 2007.

Arabic romanization should be written as follows:

Letters: ', $b, t, t h, j, h, k h, d, d h, r, z, s, s h, s, d, t, z, ', g h, f, q, l$, $m, n, h, w, y$. Short vowels: $a, i, u$. long vowels: $\bar{a}, \overline{\mathrm{i}}, \overline{\mathrm{u}}$. Diphthongs: $a w$, ay. Tà marbūtāa: t. Article: al-. For detail information on Arabic Romanization, please refer the transliteration system of the Library of Congress (LC) Guidelines. 
ستوديا إسلاميكا (ISSN 0215-0492; E-ISSN: 2355-6145) مجلة علمية دولية محكمة تصدر عن مركز دراسات الإسلام والمجتمع (PPIM) بجامعة شريف هداية الله الإسلامية الحكومية بجاكرتا، تعنى بدراسة الإسلام في إندونيسيا خاصة وفي جنوب شرقي آسيا عامة. وتستهدف المجلة نشر البحوث العلمية الأصيلة والقضايا المعاصرة حول الموضوع، كما ترحب بإسهامات الباحثين أصحاب التخصصات ذات الصلة. وتخضع جميع الأبحاث المقدمة للمجلة للتحكيم من قبل لجنة مختصة.

تم اعتماد ستوديا إسلاميكا من قبل وزارة البحوث والتكنولوجيا والتعليم العالي بجمهورية إندونيسيا باعتبارها دورية علمية (رقم القرار: 32a/E/KPT/2017).

ستوديا إسلاميكا عضو في CrossRef (الإحالات الثابتة في الأدبيات الأكاديمية) منذ ع ا • ب، وبالتالي فإن جميع المقالات التي نشرتا مرقمة حسب معرّف الوثيقة الرقمية (DOI). ستوديا إسلاميكا بجلة مفهرسة في سكوبس (Scopus) منذ .ب مايو 0 . ب.

$$
\begin{aligned}
& \text { قيمة الاشتر الك السنوي خارج إندونيسيا: }
\end{aligned}
$$

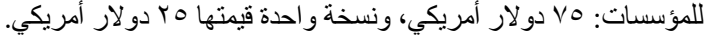

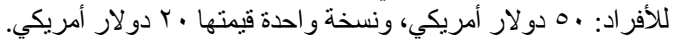

$$
\begin{aligned}
& \text { والقيمة لا تشمل نفقة الإرسال بالبريد الجوي. ونسي. }
\end{aligned}
$$

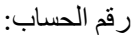

$$
\begin{aligned}
& \text { خارج إندونيسيا (دولار أمريكي): ابن }
\end{aligned}
$$

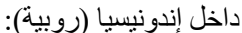

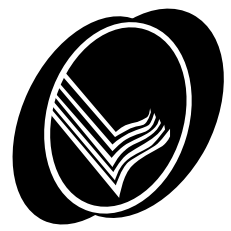




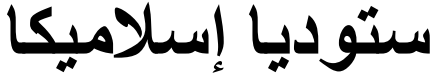 \\ مجلة إندونيسيا للار اسات الإسلامية}

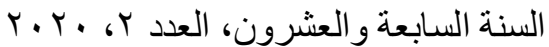

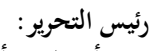

$$
\begin{aligned}
& \text { أزيوماردي أزرا }
\end{aligned}
$$

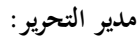

$$
\begin{aligned}
& \text { أومان فتح الرحمن } \\
& \text { هيئة التحرير: - ميف } \\
& \text { سيف المزاني }
\end{aligned}
$$

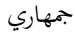

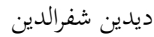

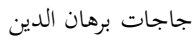

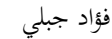

$$
\begin{aligned}
& \text { علي منحنف }
\end{aligned}
$$

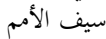

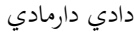

$$
\begin{aligned}
& \text { جاجانج جهراني } \\
& \text { دين واحد }
\end{aligned}
$$

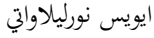

$$
\begin{aligned}
& \text { محمد قريش شهاب (جامعة شرئ شريف هداية الله الإسلامية الحكومية بجاكرتا) }
\end{aligned}
$$

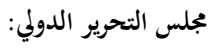

$$
\begin{aligned}
& \text { مارتين فان برونيسين (جامعة أتريخة) } \\
& \text { جوهن ر. بووين (جامعة واشنطن، سانتو لويس) } \\
& \text { محمد كمال حسن (الجامعة الإسلامية العالمية - ماليزيا) } \\
& \text { فركنيا م. هوكير (جامعة أستراليا الحكومية كانبيرا) }
\end{aligned}
$$

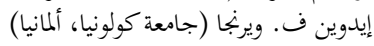

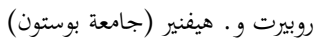

$$
\begin{aligned}
& \text { ريمي مادينير (المركز القومي للبحث العامعة بودنون العلمي بفرنسا) }
\end{aligned}
$$

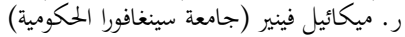

$$
\begin{aligned}
& \text { ميكائيل ف. لفان (جامعة فرينشتون) }
\end{aligned}
$$

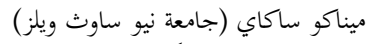

$$
\begin{aligned}
& \text { انابيل تيه جالوب (المكتبة البريطانية) } \\
& \text { شفاعة المرزانة (جامعة سونان كاليجاغا الإسلامية الحكومية) }
\end{aligned}
$$

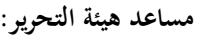

$$
\begin{aligned}
& \text { تيستريونو } \\
& \text { محمد نداء فضلان } \\
& \text { رنغكا إيكا سافوترا }
\end{aligned}
$$

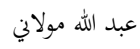

$$
\begin{aligned}
& \text { مراجعة اللغة الإنجليزية: - مبن } \\
& \text { بنيمن ج. فريمان } \\
& \text { دانيل فتريون } \\
& \text { موسى بتول } \\
& \text { توباغوس أدي أسناوي }
\end{aligned}
$$

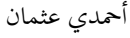





\section{لالتوايا السال|مسيا}




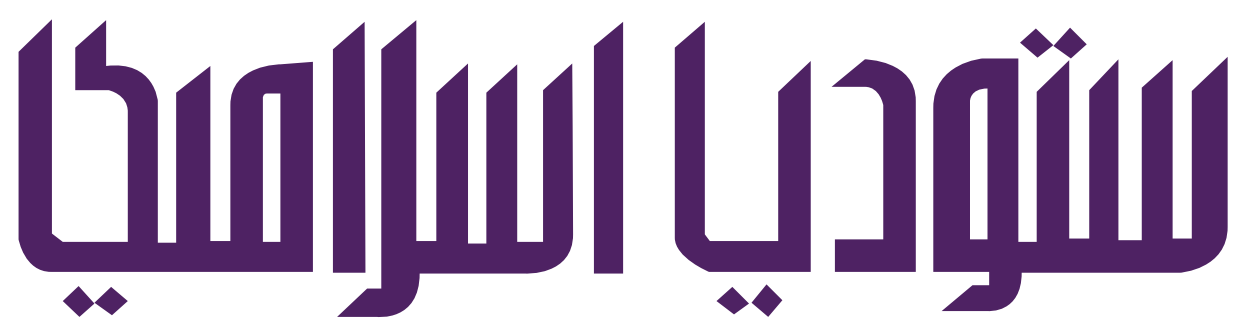

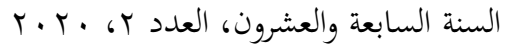

بجلة إندونيسية للدراسات الإسلامية

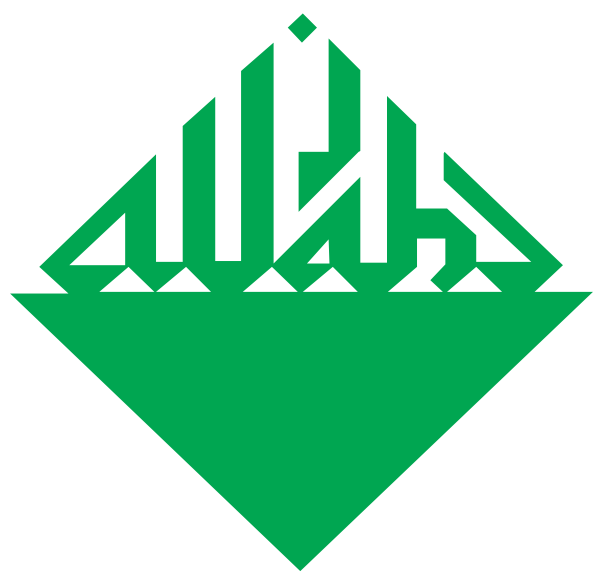

الكهناج هن أجل كولة إسلاهية

عبر المسار الديمهنراطيه:

تجبرية الحزبـ الإسلاميه الماليزيى (PAS)

محمد عرفان حلمي وأحمد علي نور الدين

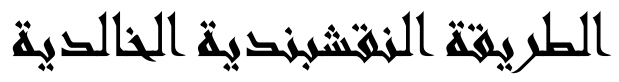

هيى تشيانجور جاواه الغربية:

تعاليمها وطتمكسها وتطوراتهما

عبد الواحد هاشم 